\title{
Economia, Democracia e Justiça em Angola: O Efêmero e o Permanente
}

\author{
Daniel dos Santos
}

\section{Resumo}

Este artigo analisa as implicações diversas em torno das disputas pela hegemonia política em Angola, basicamente após sua independência em 1975. No período anterior a este processo, organizaçóes e partidos políticos compostos e dirigidos por diferentes elites angolanas disputavam o poder do Estado na tentativa de inaugurar uma nova fase em termos de construção da soberania e dos destinos da nação angolana. $\mathrm{O}$ autor argumenta que tais tentativas, por mais legítimas que tenham sido, na realidade invertiam de maneira elitista e subordinada a trajetória histórica que Angola, enquanto nação independente e desejosa de mudança na geopolítica continental e internacional, almejava fazer. As recentes disputas internas entre as forças políticas do país prejudicam a construção de um projeto nacional e deixam de lado a grande parte do povo angolano. Com o término da disputa inscrita pela Guerra Fria, Angola perde sua importância enquanto nação estratégica e se transforma em peça do joguete internacional orquestrado pelos EUA. Dessa forma, a efetivação de uma democracia que envolva as aspiraçóes populares torna-se hoje a tarefa mais importante para a consolidação de uma inclusão positiva de Angola na política internacional

Palavras-chave: Angola; democracia; nação; projeto nacional; elites dirigentes

\footnotetext{
* Este trabalho não analisa as eleições de 1992 e o período pós-eleitoral.
} 


\section{Abstract \\ Economy, Democracy and Justice in Angola: The Ephemeral and the Permanent}

This article analyzes the many implications regarding the political hegemony disputes in Angola that basically arose after its independence in 1975. During the period prior to this process, organizations and political parties composed of and governed by different Angolan elites fought for power in the State, endeavoring to start a new phase in their efforts to shape the country's sovereignty and the destinies of the Angolan nation. The author maintains that such endeavors, however legitimate, were elitist and in reality inverted the historical path that Angola aimed for as an independent nation desiring a change in its continental and international geopoltics. The recent domestic disputes among the country's political forces have a negative impact on shaping a national project and fail to consider a large section of the Angolan people. After the cold war ends these disputes, Angola loses its importance as a strategic nation and becomes an international pawn orchestrated by the U.S. of A. Thus, achieving a democracy that reflects popular aspirations is today the most important task for consolidating the positive inclusion of Angola in international policy.

Keywords: Angola; democracy; nation; national project; governing elite.

\section{Résumé}

\section{Économie, Démocratie et Justice en Angola: l'Éphémère et le Durable}

Dans cet article, on analyse les diverses implications concernant les conflits pour l'hégémonie politique en Angola, surtout après son indépendance en 1975. Dans la période précédant ce processus, des organisations et partis politiques formés et dirigés par des élites angolaises différentes disputaient le pouvoir de l'État en cherchant à instaurer une nouvelle phase dans la construction de la souveraineté et de l'avenir de la nation angolaise. Bien que légitimes, ces tentatives déviaient de façon élitiste et soumise la trajectoire historique que l'Angola, en tant que nation indépendante souhaitant des changements dans la géopolitique continentale et internationale, voulait emprunter. Les récentes luttes internes entre les forces politiques du pays nuisent à la construction d'un projet national et négligent la plupart des Angolais. Avec la fin de la guerre

Estudos Afro-Asiáticos, Ano 23, no 1, 2001, pp. 100-133 
froide, Angola perd de l'importance comme nation stratégique et devient un jouet dans le rapport de forces international mené par les États-Unis. Ainsi, l'achèvement d'une démocratie représentant les aspirations populaires constitue aujourd'hui la tâche la plus importante en vue de l'inclusion de l'Angola sur la scène politique internationale

Mots-clé: Angola; démocratie; nation; projet national; élites dirigeantes. 

fosse 'forte', transformou-se a 'força' em 'justiça”".

Blaise Pascal

\begin{abstract}
A luta de libertação angolana no século XX deve ser enfocada, com sua especificidade própria, como intrinsecamente ligada à evolução das resistências provocadas pela expansão do sistema capitalista mundial. Nesta perspectiva, reduzir esta luta a uma dimensão puramente política significa limitá-la à conquista da independência, às disputas pelo poder político e menosprezar seu alcance. A luta de libertação nacional angolana tem, em sua base, um rico conteúdo. Sua edificação é, antes e acima de tudo, uma questão de identidade cultural, elemento essencial e permanente para a edificar suas instituiçóes próprias, fundamentado no reconhecimento das diferenças, e de elaborar um projeto social, nacional e popular baseado no diferendo. Ela se desenvolve a partir do reconhecimento dos interesses e das opinióes específicas do povo angolano, e da necessidade de um debate com a participação de todos, excluindo-se os que compactuam com interesses exteriores à nação, sobre as formas de criação de riqueza (relações sociais e econômicas, forças produtivas) e sobre o marco referencial desta organização (relações políticas e exercício do poder).

A democracia é, provavelmente, a forma de organização mais conveniente à concretização da formação social angolana, mas não deve ser confundida com uma ordem particular e "autônoma”, o Estado. Ela é, principalmente, uma forma e um princípio que organizam e articulam todos os elementos que compóem a formação social angolana, de forma aberta e não secreta, permitindo a participação de todos, totalmente imbuída da preocupação de partilha e de solidariedade, de justiça social. Ela diz respeito a cada ordem e a todas as ordens ao mesmo tempo.
\end{abstract}

Estudos Afro-Asiáticos, Ano 23, no 1, 2001, pp. 102-133 


\section{Da Importância de Angola}

O regime colonial português encarnou o encontro entre as diferentes formações sociais africanas e o nascente capitalismo português e europeu. O final do século XIX e o começo do XX marcam um período de articulação dessas formações não-capitalistas com a dominação do capitalismo europeu. De forma artificial, e segundo interesses regionais das burguesias portuguesa, alemã e britânica na região, constitui-se então um espaço geográfico, político, econômico e social denominado Angola. Mas, no período entre as duas grandes guerras e, sobretudo, após 1945, vai surgir um novo parceiro, a burguesia americana, cuja presença em Angola não cessará de crescer até 1975, e principalmente depois.

De fornecedora de escravos, Angola passa a produtora de matérias-primas (diamantes, ferro, petróleo, manganês, urânio...), produtos agrícolas (açúcar, algodão, café, sisal...) e provedora de força de trabalho barata. Para a produção da burguesia portuguesa, Angola representava, seguramente, um mercado; mas, para o capitalismo mundial, Angola era uma reserva de matérias-primas e de força de trabalho. É somente a partir dos anos 1960-1970, com a maior abertura aos investidores portugueses e estrangeiros e uma certa industrialização, que Angola se torna um mercado interessante para a produção do capitalismo mundial. Dessa forma, a dominação das indústrias de exportação acentuou a dependência da colônia em relação ao capital mundial (Torres, 1983:1102, 1107) e a burguesia portuguesa teve então de ceder maior espaço às burguesias americana e européia.

A industrialização e o desenvolvimento da empresa capitalista em Angola estavam, dessa forma, ligados ao capital financeiro português e mundial. Frágil em relação aos seus concorrentes, a burguesia metropolitana portuguesa se agarrava às suas colônias: com raríssimas exceções, a subcontratação, a joint-venture e a intermediação (ver nota 5) tornam-se as únicas formas nas quais a burguesia colonial podia se refugiar. As colônias, e Angola em primeiro lugar, permitiam-lhe realizar uma certa acumulação, ao mesmo tempo em que constituíam, com a imigração para a Europa e para a América, um meio ideal para solucionar o problema da mão-de-obra excedente. A recusa da ditadura portuguesa em conceder a independência a Angola era, antes de tudo, ditada pela necessidade de modernização do capitalismo português.

Mas a eclosão da revolta nacionalista e o engajamento dos movimentos de libertação nacional em uma guerra aberta contra o

Estudos Afro-Asiáticos, Ano 23, no 1, 2001, pp. 103-133 
capitalismo colonial tornam-se um obstáculo àquela estratégia, pois representam uma tentativa de reapropriação da história angolana. A vontade de implantar um regime neocolonial revelou-se aparentemente um fracasso, não devido à industrialização de Angola, mas basicamente pela própria descolonização (Ferreira, 1985:107). Entre 1969-1970, a burguesia portuguesa procura, então, financiar a exploração acelerada da colônia, aumentando ao máximo a valorização dos recursos angolanos. As taxas de crescimento dos principais produtos minerais (diamante, petróleo, ferro) e de certos produtos agrícolas (quarto produtor mundial de café) alcançam cifras recordes. As indústrias de transformação e os serviços também dão um salto significativo, bem como o setor financeiro, em que o capital português se alia ao capital mundial, em particular ao americano e ao britânico.

A industrialização de Angola durante aquele período não visava, pois, o desenvolvimento autocentrado do capitalismo colonial, mas sobretudo as exigências "internas e externas, políticas e econômicas, da sociedade central metropolitana", como sublinha Torres (1983:1118). O custo da guerra colonial, o "gosto" por um certo capitalismo de rendas e os esforços financeiros exigidos para este desenvolvimento precipitado favoreceram a implantação da burguesia mundial em Angola. A intervenção da África do Sul permitiu à burguesia colonial integrar-se progressivamente no espaço capitalista sul-africano e objetivar uma certa autonomia em relação à burguesia portuguesa. Esta evolução dos acontecimentos e a política portuguesa de povoamento branco constituíam um dos elementos que favoreceram a estratégia sul-africana na região, ameaçando a construção da nação angolana.

O modelo de desenvolvimento de Angola fazendo parte da zona dominada pela África do Sul, sempre na ordem do dia, estaria, assim, de acordo com a estratégia total do apartheidapós 1975, que se traduz pela dominação de uma burguesia branca com base na criação de um mercado interno com exploração de uma força de trabalho negra marginalizada. A integração deste espaço na região, principalmente em termos de capital e de trabalho, era e permanece uma necessidade do capitalismo sul-africano. Seu anticomunismo visceral não era mais que um verniz ideológico, da mesma forma que o apartheidnão se reduz a uma questão de cor de pele. Essas políticas refletiam uma estratégia racional do desenvolvimento do capitalismo sul-africano.

Mesmo que possa parecer paradoxal, a luta pela construção da nação angolana recoloca o país no seu verdadeiro contexto, a

Estudos Afro-Asiáticos, Ano 23, no 1, 2001, pp. 104-133 
África Austral. Não mais se trata de escolher entre o colonialismo ou o neocolonialismo português e a libertação nacional enquanto conquista política, mas sim entre uma integração mundial maior ou uma integração regional. A integração mundial significa a recolonização de Angola, seja através de mecanismos regionais sob controle sul-africano, seja pelo controle direto dos centros do sistema mundial, Estados Unidos da América à cabeça. Em uma perspectiva contrária, a integração regional exigiria um compromisso segundo os interesses nacionais e sociais dos países da África Austral, em um esforço de partilha e de comunhão de bens e de recursos. Esse compromisso, condição de passagem da conquista do poder político à libertação social e da possibilidade de fazer progredir a construção da nação democrática, não diz respeito unicamente a Angola, mas a todas as nações da região.

\section{E da Independência de Angola}

Às vésperas de 11 de novembro de 1975, Angola representava uma certa esperança para o Continente, pois a luta por sua independência dava continuidade a uma "tradição" iniciada outrora pela luta anticolonial e pela constituição dos movimentos de libertação. Entretanto, o movimento nacionalista angolano teve de fazer face à ditadura de Salazar, sustentada pelas grandes "democracias" do centro, reunidas em torno da OTAN. Este apoio e este alinhamento do mundo ocidental - com algumas exceções - mal disfarçam os interesses de cada um desses Estados. Com suas terras férteis, suas matérias-primas, seus recursos naturais, sua mão-de-obra barata e sua posição estratégica em relação ao Continente - o porto de Lobito e a ferrovia de Benguela - a Angola colonial se revela um botim capaz de suscitar a "mais santa cobiça"!

Depois de 1945, assistia-se ao despertar dos africanos, despertar que marcará a origem de movimentos e instituições de caráter sociocultural e político que apresentarão como resultante nos anos de 1950, em Angola, a criação de dois movimentos de libertação. Um é dirigido pela pequena burguesia urbana que se radicalizou e que transformou as reivindicaçóes culturais, motor de uma idéia nacional definida pelo espaço unificado pelo capitalismo colonial, em uma luta armada com objetivos econômicos, políticos e sociais. Esta luta, fruto do insucesso de uma tentativa de diálogo com o Estado português, apelava à participação de todas as etnias que compõem o território colonial, mas principalmente à partici-

Estudos Afro-Asiáticos, Ano 23, no 1, 2001, pp. 105-133 
pação do campesinato angolano e do embriāo de operariado das cidades. O outro é dirigido por uma fração "aristocrática" do Norte, em parte exilada no Congo (Zaire) e voltada, pelo menos em sua fase inicial, para um passado histórico do qual retira sua legitimidade. Os camponeses do Norte e os emigrados do Zaire vão constituir seus efetivos. Mesmo que este movimento tenha reivindicado inicialmente a reconstituição do antigo reino do Congo, nos anos 60 ele vai se apresentar como um movimento nacional, apesar de sua base social ter permanecido imutável.

Durante a explosão da guerra colonial, na década de 1960, surgiu um terceiro movimento político, reivindicando também para si a condição de nacional. Entretanto, não se pode determinar uma base social precisa quanto à sua origem. Este movimento surge, antes, da vontade de um dirigente dissidente de um outro movimento. Depois de ter criado seu núcleo central de direção, recrutaria sua base principalmente entre as etnias do Centro-Sul. Um quarto movimento político vai se manifestar no enclave de Cabin$\mathrm{da}$, mas sua natureza, sua forma e seu conteúdo o "excluem" da nação angolana, que é por ele combatida.

O que há de comum entre estes movimentos é também o que os separa: todos são dirigidos pelas diferentes frações das elites angolanas, sejam elas nacionais ou locais, tendo, por conseguinte, diferentes projetos. Nas vésperas da independência, algumas dessas elites recorreram com freqüência às clivagens étnicas e raciais, na esperança de compartilhar o poder nacional em uma eventual negociação com a potência colonial ou de fazer secessão e reconstituir "seu território".

A formação social angolana é o resultado da ocupação portuguesa e da imposição do capitalismo colonial como forma dominante de organização das relações sociais de produção. Esta ocupação foi exercida em um espaço econômico, social, político e cultural concreto. Marcado pela diversidade e pela diferença, este espaço é definido geográfica e juridicamente pelo direito constitucional português, pelos tratados celebrados com Portugal e pelo direito internacional. No entanto, é recente essa formação social angolana. Heimer (1990) situa sua constituição entre o fim do século XIX e o fim do primeiro quartel do século XX. Trata-se de uma formação social inacabada, pois a sociedade colonial se impôs às sociedades africanas de maneira muito lenta. Por um lado, a consolidação da hegemonia política da sociedade colonial não se concretiza senão no século XX graças ao desenvolvimento do Estado local, de seus aparelhos e de suas funções. Por outro lado, a integração

Estudos Afro-Asiáticos, Ano 23, no 1, 2001, pp. 106-133 
econômica das sociedades africanas à lógica capitalista da sociedade colonial, com sua generalização da propriedade privada e do mercado, a circulação da moeda e a "proletarização do campesinato", não se acelera senão a partir do final da década de $1950{ }^{2}$

A noção de formação social angolana expõe à luz vários elementos essenciais à evolução da Angola independente, como o desenvolvimento da pequena burguesia angolana, a construção da nação angolana e o povo. Esta pequena burguesia deveria desempenhar o papel de correia de transmissão e de ligação entre a sociedade colonial e as sociedades africanas. Entretanto, um tal papel, conseqüência de uma política de assimilação e de uma política colonial que impediu a formação de uma burguesia angolana, criou, desta forma, seu contrário. Pelo seu conhecimento de uns (racionalidade e tecnologia capitalistas) e de outros (cultura, aspirações e necessidades populares), a pequena burguesia ocupa uma posição que lhe permite mediatizar um projeto nacional. Ela é fundamental para a reprodução do sistema, ao mesmo tempo em que se transforma em seu coveiro, uma vez que deveria assumir a organização da nação.

A construção da nação angolana exige a unificação e a organização do espaço herdado do capitalismo colonial e a integração das diferentes sociedades africanas, tendo por base as suas diferenças. A nação é uma condição sine qua non da definição de uma formação social angolana acabada. Ela compreende todo o território de Angola no momento de sua independência (compreendendo Cabinda), todas as etnias e todas as raças que compóem o povo angolano. A nação significa que o povo angolano é chamado a participar plenamente na definição de seus interesses, de suas necessidades e dos meios para obter suas satisfações e sua defesa. ${ }^{3}$ Este projeto nacional deve ter como base aquilo que une o povo angolano: sua história comum e suas características específicas, o pluralismo cultural e lingüístico, a produção e distribuição da riqueza, a ajuda mútua e a solidariedade. Dessa forma, os interesses nacionais não devem dividir ou separar a comunidade nacional, nem criar desigualdades econômicas e sociais inaceitáveis para nenhum componente da nação, seja ele qual for.

Sem o povo não existe nação, e ainda menos projeto nacional. Deve- se, entretanto, distinguir o projeto de uma classe social angolana do projeto de nação. Ambos podem se cruzar, dependendo do momento histórico, mas são, na maioria das vezes, distintos, visto que o povo é o conjunto de cidadãos e não um grupo determinado. Este conjunto corresponde a uma coletividade mais ou me-

Estudos Afro-Asiáticos, Ano 23, no 1, 2001, pp. 107-133 
nos estreitamente associada e considerada em referência ao território que habita ou do qual é originária, ou seja, a nação angolana. Isso implica a posse comum de um legado histórico e a vontade de viver juntos, de partilhar não apenas a herança do passado - e, por extensão, o colonialismo português — mas também o futuro. A nação na qual se insere o povo angolano deriva de uma vontade comum de constituir uma sociedade política autônoma, ${ }^{4}$ posta a seu serviço. O povo está acima do Estado, pois este não é mais que uma forma entre outras de organizar-se a defesa dos direitos do povo contra o abuso dos projetos individuais das classes sociais angolanas, aliadas a interesses estrangeiros. A relação entre as sociedades civis e a sociedade política representa, no entanto, o cerne da possibilidade de um projeto nacional e popular, condição da construção de uma formação social angolana a ser alcançada. A pequena burguesia, a maioria camponesa e os trabalhadores angolanos formam o povo e o conjunto que deve definir os interesses nacionais.

\section{As Dominantes Sociais da Democracia}

Desde a independência, a questão do desenvolvimento econômico tem servido de desculpa ideológica às elites dirigentes no centro do sistema mundial, para restringir as legítimas aspirações do povo angolano por uma vida melhor. Por outro lado, dois países, os Estados Unidos da América e a racista África do Sul, que não reconheciam a independência de Angola, escolheram primeiramente o caminho da agressão militar. Seu furor destrutivo os terá conduzido a uma aliança com um movimento de libertação e a uma guerra extrema contra o regime angolano, causando maior desgaste que a guerra colonial, tanto no nível da perda de vidas humanas, quanto em nível de destruição das infra-estruturas econômicas e sociais (ECA-UN,1989).

Da escravidão ao trabalho forçado, da ausência de liberdade e de direitos políticos, sociais e econômicos aos massacres, a história colonial angolana está marcada pelo selo da barbárie e dos abusos cometidos pelo Estado colonial, pelos colonos e por forças políticas angolanas. Mbemba (1990) faz notar que na África isto tem sido constantemente feito em nome da democracia e dos imperativos econômicos. Os regimes políticos africanos constituem, de uma forma geral, o prolongamento dos regimes coloniais, caracte-

Estudos Afro-Asiáticos, Ano 23, no 1, 2001, pp. 108-133 
rizados por uma dominação econômica estrangeira bastante acentuada.

Esta situação se encontra embutida em um longo processo que caracteriza a formação e o desenvolvimento do sistema mundial, e daquilo que Serge Latouche chama de "ocidentalização" do mundo:

Ao se fazer a história das batalhas, escreve Claude Maurel, o colonialismo fracassou. Ele se contentou em fazer a história das mentalidades para se aperceber que esta é a maior vitória de todos os tempos. A mais bela vinheta do colonialismo é a farsa da descolonização... Os Brancos estão por detrás das cortinas, mas persistem como produtores do espetáculo (Latouche, 1989:8).

As elites dirigentes angolanas faliram em sua tarefa de construção da nação e fizeram malograr um primeiro encontro importante com a História. Depreciaram as energias, as aspirações e a solidariedade populares construídas pela conquista da independência e para quem certamente o projeto era aquele de uma sociedade mais justa e mais igualitária. Mas em vez da ruptura necessária, eles se "intermediaram", preferindo garantir o essencial dos privilégios neocoloniais das forças metropolitanas, em uma espécie de contínuo histórico. Mas a história não é linear. Portanto, não é de excluir a existência em Angola, durante os últimos vinte anos, por exemplo, de setores das elites dirigentes "populares e nacionalistas" que tentaram realizar um determinado nível de ruptura, ou que o povo angolano desistiu de suas reivindicações.

Nenhuma potência colonial e neocolonial preocupou-se com a sorte da democracia na África, até os anos 80. Pelo contrário, elas se têm mostrado ansiosas por preservar laços com os ditadores de qualquer índole, e quando uma das elites intermediadoras não faz mais negócios, essas potências utilizam todos os meios à sua disposição - golpes de Estado, por exemplo -, para substituí-la por uma outra mais conforme. Quando se sentem ameaçadas por reivindicações populares, as elites dirigentes africanas apelam então àquelas potências que não economizam meios repressivos, incluindo o desembarque de forças militares.

Constata-se, porém, que os povos que formam Angola, verdadeiros "deserdados e condenados", não interessam nem a uns nem a outros. Após uma guerra e uma onda de preocupação pelos "direitos do homem", principalmente os políticos, eis que estes mesmos Estados do centro se transformam nos arautos da democracia e decidem impô-la em Angola! Graças ao desmoronamento

Estudos Afro-Asiáticos, Ano 23, no 1, 2001, pp. 109-133 
do comunismo europeu, o Ocidente descobriu, maravilhado, que a democracia, considerada como um valor seu, alcançou um status científico e político na medida dos seus sonhos. A democracia é um "valor universal e natural", o remédio certo contra o mal de que sofre o regime angolano. Este mal é político. O nacionalismo, a libertação nacional e a justiça social passam a ser encarados como obstáculos à realização da felicidade do povo angolano, quando na verdade o destino do povo angolano foi sempre a preocupação menor dos bush, dos clinton, dos major, dos mitterand ou dos chirac. A hipocrisia não se detém aí...

Os missionários se prestam a fazer as lições e as moralidades democráticas, acompanhados pelos especialistas em participação popular (as ONGs), pelos especialistas em direito constitucional e "democrático", seguidos pelos mestres da economia livre e dos senhores do mercado. Em um ponto todos estão unânimes: o casamento entre o mercado, a propriedade privada, a livre empresa e a democracia é o único remédio natural e possível para Angola. Como na antiga época colonial, todos se lançam, mais uma vez imbuídos de seu eterno espírito paternalista, ao assalto das regiões angolanas, selvagens e atrasadas, onde seres ignorantes e primitivos os recebem como salvadores! ${ }^{6}$ Durante uma entrevista ao jornal francês Le Monde (14/12/90:4), o Cardeal Nascimento afirmou que:

Os amigos de Angola amam as riquezas do país muito mais que seus habitantes: se Angola tivesse menos ouro, menos petróleo, menos algodão, menos diamantes ter-nos-iam deixado em paz [...]. O mais importante é pôr um ponto final à guerra. Sem a guerra não mais teríamos a necessidade de mendigar.

Todos se preparam para o grande dia. Financiarão as eleições e providenciarão as urnas, controlarão os eleitores, verificarão os direitos dos cidadãos angolanos à participação, aconselharão sobre o que deve ser a democracia - tudo financiado, já há muito tempo, por partidos políticos que escolheram. Após o colonialismo, o povo angolano chegaria, então, a uma civilização pensada e organizada para ele. Civilização que outros, em outras partes, já destinaram à recolonização. (cf. Lique, 1991:13-15; Cattaghy (1991); Harbeson e Rothchild, s/d: 39-68)

\section{A Sombra da Economia sobre a "Democratização"}

Esta mudança de atitude política das potências do centro, sobretudo dos EUA, em relação a Angola, está ligada, em parte, à

Estudos Afro-Asiáticos, Ano 23, no 1, 2001, pp. 110-133 
sua debilidade econômica. Da articulação de uma ordem oficial a uma desordem "informal", hoje o sistema mundial atravessa um período de desordem mal gerenciada e mal controlada. O sistema mundial vem se modificando de um período para outro mas, por razões estruturais (seu lugar no sistema) e políticas (a intermediação de suas elites e a guerra de agressão conduzida pelos EUA e pela África do Sul), Angola não se ajustou. ${ }^{7}$ Em nossos dias, a economia internacional caracteriza-se por uma "intensificação das trocas comerciais" entre os países do centro e uma "mundialização" e "interpenetração de capitais" (Amin, 1991:8), pela prestação de serviços e pelas indústrias de ponta que vêm massivamente se valendo do conhecimento. A RST (Revolução Científica e Tecnológica) permitiu aos países centrais aumentarem consideravelmente a parte de produção de bens sintéticos, mais flexíveis e mais versáteis que os produtos tradicionais, setor em que os africanos periféricos ainda podem esperar ocupar um lugar. Com baixos índices de produção e de acumulação de capital e uma dívida substancial, aos quais vêm se incorporar os efeitos perversos da guerra, Angola se afunda em uma extrema dependência do mundo exterior, contado apenas com um único produto, o petróleo.

Visto sob este aspecto, Angola teria "perdido" sua importância. A queda da URSS e dos países do Leste europeu faz diminuir seu valor geopolítico e militar. Entretanto, ainda que mais vulnerável às pressões e dominações do centro, Angola está, de uma forma ou de outra, inserida na economia mundial e submetida à sua lógica. Os Estados do centro manifestam um certo interesse e continuidade em preservar a reserva que Angola pode representar, em se tratando de matérias-primas e de força de trabalho, ao preço da manutenção da polarização do sistema e da miséria extrema dos camponeses e dos trabalhadores angolanos.

A crise econômica se eterniza e abala, de igual forma, tanto um pólo quanto outro. É uma crise do sistema mundial: "Trata-se de uma crise geral do modelo de acumulação no sentido de que a maior parte das formações sociais do Leste e do Sul são incapazes de assegurar uma reprodução ampliada e às vezes também uma reprodução simples" (Amin, 1991:11).

Daí a necessidade de restruturar o conjunto do sistema, movimento que provoca a desvantagem visível, a desordem que o caracteriza e a ineficácia de certos mecanismos de regulaçáo econômica (o mercado) e de regulação política (os mecanismos de estruturação da hegemonia mundial). Ao mesmo tempo, os Estados Unidos e a sua posição hegemônica, econômica e financeira $(\mathrm{Cu}-$

Estudos Afro-Asiáticos, Ano 23, no 1, 2001, pp. 111-133 
mings, 1991:205-6) devem ter em conta a força de antigas potências, uma na Europa (Alemanha), a outra na Ásia (Japão), com as quais deveria compor a direção da economia mundial. ${ }^{8}$ A Guerra do Golfo ilustrou até que ponto a posição americana está abalada. Cada vez mais seu papel se resume ao de gendarme do sistema mundial, porque sua potência militar segue inconteste (Chomsky:1991), o que não significa declínio do seu poder econômico e financeiro.

No outro pólo, a lógica de ajustamento estrutural se inscreve na procura de soluções para a acumulação de capital e procede à imposição do mercado como mecanismo de regulação e de unificação do sistema. Onde ainda possa existir possibilidades de resistência, mesmo que ínfimas, a imposição da "democratização" é um elemento da "geocultura", daqueles "quadros de referência cultural no interior dos quais o sistema mundial opera" (Wallerstein, 1991:11). Isto faz parte de um longo movimento histórico que visa, a cada etapa, maior integração das periferias à lógica do centro:

O Ocidente fez mais que modificar seus modos de produção, ele destruiu o sentido de seu sistema social ao qual esses modos estavam fortemente aderidos. Desde então, o econômico tornou-se um campo autônomo da vida social e uma finalidade em si mesmo. As velhas forças onde predominava o ser mais, foram substituídas pelo objetivo ocidental do ter mais. (Latouche, 1989:27)

Para o Banco Mundial e para o Fundo Monetário Internacional a "democracia" estaria melhor servida se Angola aplicasse seus programas de ajustes, cujo objetivo principal é o de reforçar o mercado em relação ao Estado. Segundo essas instituições, a privatização da propriedade pública é, por excelência, a garantia do pluralismo, assim como um mercado mais livre é a certeza da descentralização de decisões, da multiplicação de centros de poder e, por conseguinte, do fortalecimento da "sociedade civil" (nesse sentido, sociedade civil é sinônimo de sociedade "burguesa"). Entretanto, esses programas ampliam, na maioria das vezes, a inflação e o desemprego, ao mesmo tempo em que controlam os salários, reduzem as fontes de financiamento e cortam os subsídios. Como conseqüência, a maior parte dos ganhos dos cidadãos angolanos diminuíram em termos reais: $40 \%$ deles vivem abaixo do nível de pobreza absoluta, o que leva a um aumento do setor informal e ao mercado paralelo (Morais, 1990). A esta queda real dos ganhos veio se juntar o agravamento dos problemas sociais "crônicos" da economia, da desnutrição, das mortes prematuras e do desespero.

Estudos Afro-Asiáticos, Ano 23, no 1, 2001, pp. 112-133 
Para estes cidadãos angolanos, o ajuste estrutural assemelha-se a um massacre, e não ao reforço da sociedade civil. Rapidamente se dão conta de que mulheres e crianças são as primeiras vítimas destes programas. O Unicef prega abertamente um "ajuste estrutural com face mais humana" (Pearce, 1989). A necessidade de "ajuste" da economia angolana certamente não está em pauta, dado o êxodo massivo dos quadros portugueses quando da independência, os males causados pela guerra e as políticas econômicas após 1975 (Martin e Johnson, 1989; Lubati, 1989; ECA-UN, 1989). Isto explica, em parte, a gestão deficiente e desastrosa da produção e da distribuição nacionais. Os problemas se situam, antes de tudo, no nível das soluções que o Banco Mundial e o FMI querem impor (Africa South, 1990).

A especificidade angolana, relacionada ao clima de guerra e às despesas militares daí decorrentes, são conseqüências de uma política cega por parte dos Estados Unidos e da África do Sul, tanto quanto da cobiça das elites políticas angolanas. A dispensa de 40 a 50\% dos empregados públicos de Angola não pode ignorar o fato de que, na maioria das vezes, o Estado é o único empregador possível. Portanto, é fundamental ativar o sistema de produção, criar programas de formação da força de trabalho e de proteção de seus direitos sociais, pois a preservação de uma reserva de mão-de-obra não qualificada aumenta a miséria. Por isso, a privatização das empresas públicas angolanas representa um embuste, pois não reforça a propriedade, a produção e o consumo nacionais para o desenvolvimento de um mercado autocentrado. Ela deve favorecer o investimento produtivo, nacional e internacional, e a criação de mecanismos nacionais de acumulação de capital, em lugar da compra e venda de serviços e de equipamentos muitas vezes inúteis. Esta privatização não deve levar Angola a uma renovada dependência econômica em relação aos centros. A nova ordenação do sistema mundial constitui uma renovação dos Pactos Coloniais e introduz, por intermédio da privatização, o domínio dos centros sobre as fontes de recursos naturais da periferia, mesmo onde isso já não era mais uma realidade ou corria o risco de o deixar de ser.

O "Estado" angolano caracteriza-se pelos poucos serviços que oferece a seus cidadãos, tanto nas áreas social e econômica quanto na cultural, apesar dos esforços realizados após 1975. Comparados ao regime colonial, estes serviços estão realmente "democratizados", mas se os comparamos às reais necessidades do povo angolano, damo-nos conta de que está longe de alcançar seus objetivos. $\mathrm{O}$ ajuste estrutural não apenas evidencia este resultado

Estudos Afro-Asiáticos, Ano 23, no 1, 2001, pp. 113-133 
mínimo, como acentua o diferendo aumentando as desigualdades e a injustiça dessa nova distribuição. Defrontamo-nos, assim, com uma contradição paradoxal! Em uma situação de desenvolvimento débil das forças produtivas e de pobreza, a distribuição da riqueza nacional é desigual, menos desigual, porém, que quando o desenvolvimento conduz a uma nova riqueza. Isto póe em destaque a importância dos mecanismos e das modalidades de distribuição da riqueza nacional e das transferências desta mesma riqueza de Angola para os centros e a urgente necessidade de as redefinir segundo os interesses nacionais.

Em tal conjuntura, a democracia é uma ilusão! Contam apenas a aparência e o formalismo. $\mathrm{O}$ povo angolano torna-se um elemento passivo da vida social. A qualidade é substituída pela quantidade, prelúdio do desenvolvimento e da ampliação da reifica ção. 'E é isso que consolida, por um lado, a tendência à uniformização de todos os aspectos da vida no interior do sistema mundial (integração/racionalidade) e, por outro lado, a tendência à redução da consciência das sociedades civis a um simples reflexo. Donde se estabelece a lógica da reificação: ampliar as bases da acumulação privada do capital impondo a "idolatria do dinheiro". Tudo é mercadoria, tudo está à venda. O que leva simultaneamente ao aumento das possibilidades de realização de lucro e das condiçôes de edificação de um consenso ideológico em torno dos valores econômicos, em particular da exploração da força de trabalho e do exercício da governabilidade.

Mesmo que a universalização do modo de desenvolvimento, segundo o centro do sistema mundial, seja claramente marcada por um determinismo econômico, a nação angolana deve definir seus interesses e sua escolha nesse contexto. Após a independência, os Estados centrais intervêm regularmente na vida econômica, política e cultural de Angola para estabelecer e para preservar as condições de reprodução do sistema. Mas esta intervenção não é exclusividade de Angola. $\mathrm{Na}$ África, esses Estados têm enviado as forças militares locais para se livrar das elites locais que se tornaram incômodas. Porém, mais sutil e freqüentemente, os centros forjaram os mecanismos econômicos, financeiros e comerciais que ligam inexoravelmente os países africanos às metrópoles, que corrompem o poder político (Péan, 1988; Couvrat e Plesse, 1988) e provocam danos ecológicos consideráveis (Bouguerra, 1985; Vidal, 1992). Os Estados do centro e suas instituições introduziram um novo modo de intervenção na vida africana: "o condicionamento político". Este permite peneirar a ajuda, outro mecanismo

Estudos Afro-Asiáticos, Ano 23, no 1, 2001, pp. 114-133 
financeiro que deu suas provas de utilidade e benefício em um mesmo sentido, ou seja, o centro sempre leva vantagem em relação à periferia. Desde então os centros utilizam este mecanismo como uma forma de acelerar os processos de integração da África à acumulação mundial. A atual reforma política não objetiva o desenvolvimento autônomo e autocentrado da formação social angolana, mas a liberalização do mercado. Não é apenas isto que está em jogo em Angola, mas constitui o objetivo principal.

Notemos, entretanto, que esta ajuda, que raramente alcança um nível significativo, não respeita os compromissos assumidos internacionalmente, mesmo em relação ao orçamento dos países "beneficiários". Ela é direcionada de forma tênue às forças econômicas e populares. Ela não reforça os grupos nacionais nem o mercado interno, elementos de uma autonomia tão necessária ao desenvolvimento da periferia angolana. Esta ajuda não apóia o desenvolvimento e a participação verdadeira das sociedades civis na democratização do país. Pelo contrário, ela incrementa a corrupção do aparelho político e mascara as relaçóes sociais e econômicas concretas, insistindo no formalismo político que é próprio da imagem do modelo democrático dominante dos Estados centrais:

Nós elogiamos os méritos do Estado de direito, da eleição e da representação, e temos razão; mas esquecemos que milhares de nossos contemporâneos vivem a maior parte de suas vidas em um mundo - o mundo da produção e da empresa - onde o direito apenas se aplica quando se faz respeitado pela força, e onde o poder é exercido segundo os modelos que se situam em algum lugar entre o feudalismo e o despotismo esclarecido, mas que não dizem certamente respeito à democracia. (Latouche, 1989: 27)

\section{O Jogo Democrático: Submissão e Resistência}

Do ponto de vista etmológico, a democracia reúne dois ingredientes, o povo (demos) e a potência (kratos), e faz referência a um sistema no qual a soberania pertence ao conjunto de cidadãos e não apenas a um ou alguns dentre eles. Ela é um valor e uma exigência moral, resultante da insatisfação com o presente, da busca da restauração de uma situação de soberania e da demanda por uma melhor ordem político-social. Como forma de organização da vida em sociedade e como modo de regulação das relações sociais, a democracia deve juntar as liberdades política, cívica e individual com a ordem econômica, a igualdade social e os direitos coletivos. Tenta-se, muitas vezes, separar o político do social e do

Estudos Afro-Asiáticos, Ano 23, no 1, 2001, pp. 115-133 
econômico mas, na verdade, são inseparáveis porque complementares. A totalidade democrática define-se pela articulação dessas ordens como condição necessária à libertação dos indivíduos de todos os condicionamentos que os oprimem, à sua participação plena no estabelecimento de regras que têm que observar, e em todas as esferas da vida social.

A democratização da formação social angolana, segundo a versão dos Estados do centro, reclama, de forma curiosa, o debate sobre o sufrágio universal no século XIX, quando a burguesia européia não o aceitava por não ter a certeza de que ganharia as eleições. De fato, as eleições tornaram-se um caminho de legitimação da dominação desta classe e da emancipação do Estado/poder político mais que uma ferramenta da libertação do cidadão/povo. Para que a democracia seja efetiva e conduza à emancipação do cidadão angolano, com o aumento da sua participação nas decisóes e na criação de regras de conduta, ela deve tornar seu o debate sobre a distribuição das riquezas nacional e mundial, com a preocupação de justiça social e de eqüidade. Quando as elites periféricas, sob a pressão de seus povos, demandam uma Nova Ordem Econômica Internacional, os centros do sistema mundial fazem uma frente comum para bloquear toda possibilidade significativa de mudança, pois hoje eles se unem para impor uma Nova "Desordem" Mundial: "O desenvolvimento é a aspiração ao modelo de consumo ocidental, à potência mágica dos brancos, ao status ligado a esse modo de vida" (Latouche, 1989:27).

É sob esta perspectiva que se deve compreender porque o centro "democrático" levou tanto tempo para se interessar pela democratização da periferia. Mesmo atualmente, a dúvida persiste. Em 1992, os Estados Unidos queriam, antes de tudo, fazer desaparecer o regime angolano para instalar no poder uma outra facção, mesmo antidemocrática, que lhe fosse mais favorável; como tal solução mostrou-se irrealizável, declararam-se, naquela altura, dispostos a aceitar um regime dividido entre os dois. Não são, no entanto, os centros mesmo que vêm reivindicando o "pluralismo", mas sim a própria sociedade angolana. $\mathrm{O}$ centro se contenta com um formalismo democrático, que garantirá sua supremacia e legitimará a submissão da periferia angolana, capaz de conter as forças populares e nacionais. A era da paz e da prosperidade, tão anunciada após a Guerra do Golfo e a assinatura dos acordos de Bicesse, já não representam mais um paraíso ao alcance das mãos! Este fim de século não inaugura um período de justiça e de fraternidade entre os dois pólos do sistema mundial, mas uma confrontação possível

Estudos Afro-Asiáticos, Ano 23, no 1, 2001, pp. 116-133 
e violenta (Rufin, 1991; Dowden, 1992). O desaparecimento da URSS, a consolidação da Comunidade Européia, o Tratado de Livre-Comércio das Américas e o declínio do Atlântico comercial e militar indicam claramente que os centros empunham suas armas para uma nova conquista colonial.

$\mathrm{Na}$ época da "globalização do capital", a democratização de Angola põe em jogo a oposição en tre os centros e a nação angolana, e, por outro lado, entre as forças nacionais e populares e as forças intermediadoras. O movimento de reificação do sistema se encaminha para uma nova etapa, na qual o centro briga por uma maior uniformização do mundo, caracterizada pela cobiça ilimitada do mercado livre e da propriedade privada. Isto implica uma nova legitimação da intermediação das elites políticas e econômicas angolanas. Basta escutar as exageradas declaraçôes e profissōes de fé de certos partidos políticos angolanos, como se tivessem, de repente, descoberto um novo "deus". À medida que cai o véu, os cidadãos que formam a nação angolana responderão a este movimento conforme a história desses últimos séculos, com estratégias de ruptura sincrônica, no início, e diacrônica, no prosseguimento. Tais estratégias têm sua fonte nos mecanismos forjados pela libertação nacional que eles estendem a um projeto nacional e popular, condição da construção de um desenvolvimento autocentrado e de uma distribuição mais justa (Amin, 1990a e 1990b).

As elites angolanas perderam, em 1975, um momento crucial de reapropriação da história nacional. Repetiram o erro em 1992, pois não entenderam a importância desta dialética própria das sociedades civis, e do lugar que estas devem ocupar na definição dos interesses nacionais. Os numerosos partidos "emergentes" se autodenominam de "partidos cívicos" para se diferenciarem dos três mais antigos. Entretanto, isto está relacionado a uma grosseira manipulação política, já que as sociedades civis angolanas devem permanecer autônomas ${ }^{10}$ e encontrar, por elas mesmas, a forma e o conteúdo de sua expressão política. Elas não se confundem com o poder político ou com os partidos e devem, pelo contrário, constituir-se como o verdadeiro local da soberania nacional, de reivindicação e de resistência moral, econômica, social e cultural. Daí a importância do código de coabitação nacional proposto por Gentil Viana (entrevista ao Jornal de Angola, 22/12/1991:1 e 7; e "Sobre o Código de Convivência Nacional", Jornal de Angola, 5/1/1992.). Este se ocupa em estabelecer "um abrangente acordo de princípios organizados em normas" que garantam a regulação das relações entre os cidadãos e os partidos políticos, por um lado,

Estudos Afro-Asiáticos, Ano 23, no 1, 2001, pp. 117-133 
e, por outro, entre esses últimos. Existe, porém, um problema: a distinção feita entre paz militar e paz civil se presta à confusão, uma vez que qualifica o conflito "angolano" como "guerra civil". As sociedades civis angolanas sofreram uma guerra entre, por um lado, duas formações políticas e, por outro, uma guerra de agressão com invasão e conquista de forças militares estrangeiras. A paz civil só pode ser regulada pelas próprias sociedades civis, o que remete às relações entre as classes e os grupos sociais angolanos e sua vontade de edificar a nação angolana, enquanto a paz militar depende dos partidos políticos beligerantes e das forças estrangeiras envolvidas. A paz civil e a reconciliação nacional podem e devem ser obtidas, não por um código definido pelos partidos políticos, mas pela organização e fortalecimento das sociedades civis, de modo a permitir a estas a imposição sobre os partidos políticos angolanos e sobre as forças estrangeiras. Gentil Viana realizava uma corrida contra o relógio, provocada pelo absurdo da manutenção, a qualquer preço, das eleições em setembro de 1992, o que indica a sede de poder da sociedade política angolana. $O$ código de coabitação nacional deveria constituir um dos meios que permitiriam às sociedades civis se impor e responsabilizar os partidos políticos e o Estado.

Verdade que a democracia não elimina a relação dominantes/dominados, mas reduzi-la a um caráter político exclusivo significa obrigá-la a permanecer abstrata e a reproduzir as piores desigualdades que marcam tão especificamente o sistema mundial: a arrogância e o egoísmo, de um lado, a miséria e a humilhação, de outro. Essa situação é encontrada no interior de cada pólo do sistema mundial (centros e periferias). Ao tornar-se concreta, a democracia deve englobar todas as esferas da formação social angolana, a começar pela economia. Ao se opor ao efêmero, que caracteriza as relações político-econômicas, a democracia torna-se o espaço no qual se tecem as relaçôes sociais duráveis e próprias das sociedades civis. Somente uma democracia que responda a tais exigências pode produzir os meios que a periferia angolana necessita para restringir a reificação e a cega cobiça que marcam a globalização do capital, e para expandir as possibilidades de construção da nação e de formação de um Estado angolanos, condição para uma melhor redistribuição.

Os anos 90 apresentam, independente dos regimes políticos, certos indícios de novas formas de resistência periférica à desordem reinante, fundamentalmente diferentes das formas passadas. Elas acentuam a oposição centro-periferia, enquanto os novos

Estudos Afro-Asiáticos, Ano 23, no 1, 2001, pp. 118-133 
ideólogos afirmam não existir resistência ou oposição importantes à "nova ordem" unipolar e "democrática", dirigida pelos Estados Unidos (Carpenter, 1991:27). Estas resistências se aglutinam em torno das formas e das expressōes culturais, sem abandonar as questôes políticas, econômicas e sociais (Latouche, 1991). Elas trazem à luz a existência e o direito de afirmar a diferença e o diferendo. $\mathrm{Na}$ diferença ressalta-se aquilo que distingue e separa uns dos outros, a cultura em seu sentido amplo. A diferença refere-se ao conjunto de caracteres que tornam a distinção não apenas possível, como também clara. Sua definição plural constitui, então, sua unidade. Discerne-se, no diferendo, o que pode ou deveria uni-los e que impõe, desde o início, um debate "a propósito do justo e do injusto". "' O diferendo é o domínio da possibilidade do desacordo e da contestação. Ele é plural, pois baseia-se na diversidade de opiniões e na oposição de interesses, ou seja, o reconhecimento da possibilidade de um confronto e de um compromisso entre as partes.

Estas resistências são concernentes a valores fundamentais, ou seja, à concepção de uma "visão de mundo" própria, à relação entre a vida e o mundo que a cerca (cultura/natureza) e que guia a construção das solidariedades, das alianças e das oposiçôes. A geocultura do sistema mundial caracteriza-se por sua pretensão universalista e pelos valores ideológicos que a contradizem: o racismo e o sexismo (Wallerstein, 1991: 12, 158-83; 1983: 73-93). A imposição da reificação e de tudo aquilo que ela comporta como valores do centro do sistema revela um desprezo pelas pluralidade e identidade da periferia. A ideologia etnocêntrica, fortemente carregada de racismo e de sexismo, já não mais se camufla! Estes dois componentes da geocultura fizeram-se tão importantes e visíveis que se tornaram, novamente, nos dias de hoje, objeto da ciência e das lutas políticas entre os dois pólos do sistema e no interior de cada um deles. ${ }^{12}$

Esta contradição no nível da geocultura produz efeitos perversos que apontam em direção às oposiçôes mais evidentes. Tomando como referência a experiência angolana, ela se traduz pelas contradições que opõem a nação e os intermediários. Mesmo entre aqueles que denunciam o racismo e o sexismo no centro, muitos aceitam o universalismo do sistema mundial e agem em Angola com a arrogância do dominante (classe política e dos negócios), na melhor das hipóteses com um paternalismo de bom tom (igrejas, ONGs) ou com ignorância "inocente" (a massa desinformada). Sentem-se, apesar de tudo, parte integrante do centro. As possíveis

Estudos Afro-Asiáticos, Ano 23, no 1, 2001, pp. 119-133 
resistências culturais da periferia angolana têm assim o seu duplo, aqueles que aceitam a intermediação, na maioria das vezes de forma consciente (as elites políticas e suas clientelas) e aqueles que hoje não renegam a nova "solução milagrosa". Sedentos de poder, confundem a democratização formal com a propriedade privada e o mercado livre. $\mathrm{O}$ sistema mundial e seus centros investem consideravelmente na desinformação e na difusão massiva de uma ideologia social-democrata, centrista, soft, consensual e dogmática (cf. Huyghe e Barbés, 1987; Herman e Chomsky, 1988; Chomsky, 1989; Terray, Moscovici, Doise et alii, 1990; Devouassoux e Labéviére, 1989; e, principalmente, Eudes, 1982), objetivando assegurar a coesão e a adesão de todos os cidadãos à geocultura:

Este sistema de "comunicação" é o espelho de uma sociedade da qual está ausente todo valor de compartilhar. $\mathrm{O}$ espelho não reflete senão o horror. Ou a insignificância. Onde, na percepção do sujeito, o mundo tornou-se em horror. Ou jogo. A conseqüência? Uma poluição permanente da alma, o sentimento de impotência, a psicose da solidão, a recusa do outro e da história. Um manto de sofrimento jogado sobre as pessoas. (Ziegler, 1989:45)

Esta ideologia caracteriza-se pelo predomínio dos valores econômicos da modernidade tal como concebida no Ocidente: o produtivismo, a rentabilidade, a eficácia tecnológica e a manutenção exagerada da expansão de trocas desiguais, tudo isso conjugado com a avidez de lucros imediatos. Face a uma ética falsa e uma moral imoral, as resistências angolanas, em particular a luta por uma democracia concreta e completa, dependem muito mais dos cidadãos e de suas instituições que dos partidos políticos e do Estado. O cidadão angolano deve distinguir esses dois níveis de ação para exercer plenamente seu direito a uma livre escolha política e para exigir contas aos que lutam pela responsabilidade e não pelo privilégio, de exercer o poder em seu nome.

\section{Quando a Democracia é Também Justiça}

Insistindo sobre o formalismo e a dimensão política da "democratização", o sistema mundial finge ignorar as relações sociais concretas e reduz a liberdade dos cidadãos angolanos à emancipação do "pretenso Estado" e do mercado locais. Esta autonomia conquistada emancipa-se em relação às sociedades civis, visto que ela é uma condição de legitimação da intermediação e da dominação do mais forte. A democracia angolana não será concreta a me-

Estudos Afro-Asiáticos, Ano 23, no 1, 2001, pp. 120-133 
nos que venha a ser o mecanismo de libertação das sociedades civis, do cidadão angolano coletivo e individual. O exagero daqueles partidos políticos angolanos que celebraram a "vitória" do formalismo democrático ilustra-se por uma vasta campanha de desinformação, manejada pelos centros do sistema, para os quais o conceito de democracia está impregnado de esperas desmedidas e portador de falsas esperanças. Estes mesmos partidos fizeram crer que a realização da democracia formal resolverá os problemas não apenas políticos, mas sobretudo sociais e econômicos da formação social angolana, e que somente o capitalismo é compatível com a democracia. Pretendem que as democracias formal e política coloquem todos os cidadãos em um plano de igualdade, ou seja, que ela conduzirá a uma distribuição mais igual e mais justa dos benefícios e dos recursos econômicos e sociais.

A democracia em Angola não aparecerá como uma forma de organização mais ordenada, mais consensual e mais estável. Sua própria natureza indica que ela constitui um compromisso que se constrói continuamente entre a desordem, o desacordo e o movimento. Certamente ela conduzirá a uma administração política mais aberta, mas isto não significa que a economia também o será. ${ }^{13}$ Certos objetivos da organização da economia angolana, definidos pelo Banco Mundial e pelo FMI - ou seja, o direito de possuir a propriedade e reter os lucros, a função de "depuração" do mercado, a liberdade de produzir sem regulamentação estatal e até mesmo a privatização das empresas públicas - podem se tornar obstáculos à democratização de Angola. O "Estado" democrático a ser construído em Angola terá a necessidade de deduzir taxas e impostos e regulamentar os mais "gulosos" para evitar, o mais possível, os monopólios, os cartéis e os oligopólios e para proteger os direitos da coletividade da intromissão abusiva dos que possuem a propriedade. Assim, a democracia se definirá pela pluralidade das formas de propriedade, sem ceder à tentação de privilegiar uns em detrimento de outros. Isto significa simplesmente que certas noçôes de liberdade econômica, em geral levadas adiante pelos modelos neoliberais, não são sinônimo de liberdade política. Na maioria das vezes, as primeiras impedem as segundas. Certos partidos políticos, por exemplo, compram, literalmente, o voto do cidadão, outros se vendem aos países estrangeiros para obter apoio financeiro e material.

Um futuro "Estado" democrático angolano deverá prestar contas às sociedades civis. Daí a necessidade urgente de criar organismos possuidores de direito de veto, totalmente independentes

Estudos Afro-Asiáticos, Ano 23, no 1, 2001, pp. 121-133 
dos partidos políticos e do Estado e capazes de controlar e verificar as ações destes. A meta dessas instituições civis seria a de afirmar a soberania da nação, de vigiar a execução do mandato confiado à sociedade política e de garantir um verdadeiro Estado de direito democrático.

A independência ou a separação dos poderes não é um problema exclusivo da sociedade angolana. Constantemente podemos encontrar o mesmo problema nas "democracias" dos países do centro. Contrariamente ao que pensam os partidos políticos, nada impede a criação de instituições que emanem das sociedades civis e que assumam um papel de "guardiāo" constitucional. O Estado e os partidos políticos não são responsáveis apenas diante do Parlamento, mas também diante do povo. O Parlamento, peça-mestra da sociedade política, é por excelência o lugar de legitimação do exercício do poder, ao passo que a democracia exige que este lugar seja assumido pelas sociedades civis.

A questão da distribuição econômica e social é essencial ao debate sobre a democratização da formação social angolana e de suas relações com o centro do sistema mundial. Da forma por ele considerada, esta democratização não traz necessariamente em seu rastro o crescimento econômico, a paz social, a eficácia administrativa, a sã, honesta e aberta governabilidade, a harmonia política, os mercados "livres" e eqüitativos, o "fim das ideologias", e menos ainda, o "fim da história"! Desde a colonização, os episódios de resistência do povo angolano, ao contrário, têm sempre como pano de fundo o desenvolvimento, em diferentes níveis, de ideologias nacionalistas e a tentativa de retomada de sua história. Esta reestruturação se baseia na força do movimento de reificação e insistência sobre o mercado, sobre a privatização e sobre o formalismo eleitoral. Ela só se interessa pela criação, na periferia angolana, das condições necessárias à reprodução do capital, pela reserva da força de trabalho e das matérias-primas. Para que serve um crescimento econômico, se os mecanismos e as regras de distribuição em Angola não favorecem os produtores e os consumidores locais, mas principalmente as empresas transnacionais, os Estados do centro, as pequenas e médias empresas internacionais e as elites compradoras locais?

A democracia se resumiria, então, às formas de legitimação da reestruturação do sistema mundial e do lugar que ele destina a Angola? Ela deve deixar de ser um princípio de legitimação, que a reduz a formas de governabilidade baseadas na autoridade do mais forte $^{14}$ e reduz o espaço político angolano a uma legitimidade reco-

Estudos Afro-Asiáticos, Ano 23, no 1, 2001, pp. 122-133 
nhecida do exterior, para se transformar em um princípio de justiça, no fio condutor da organização da nação angolana como uma totalidade. Sua definição, enquanto legitimidade, repousa sobre a modernização liberal ocidental que privilegia a liberdade individual, definida pelo direito como forma de limitação do poder. É também nessa ideologia liberal que se encontra a noção de liberdade inovadora do direito como fundamento do poder ilimitado da vontade geral (soberania). E aí temos posiçōes contraditórias: uma, afirmando a precedência do direito sobre a legislação, limitando, assim, a força da soberania; a outra estabelece que todo "contrato social" é possível a qualquer momento. Para esta, deve se fazer tábua rasa e criar a ordenação jurídica da sociedade de forma voluntarista. Aqui, o direito e a lei se confundem e ambos pretendem ser a expressão da vontade geral. E é feita a jogada, visto que esta vontade geral é identificada com a soberania do Estado e não da nação. Aparentemente contraditórias, estas duas proposições formam uma unidade que se tornou a coluna vertebral do Estado democrático liberal. ${ }^{15}$

Esta confusão entre legitimidade e legalidade provoca um debate muito importante, o do Estado de direito. Ele encontra suas fontes na monarquia absoluta francesa para a qual "a soberania é limitada pela lei divina, natural e constitucional" e na crítica dos iluministas (Montesquieu em particular), principalmente no "mito fundador" do formalismo democrático que é a separação dos poderes (executivo, legislativo e judiciário). Uma outra fonte, provavelmente mais importante, é a monarquia constitucional inglesa. Ela pretende conceder a supremacia aos "direitos individuais dos sujeitos" e o papel principal de controle constitucional ao jurídico (Lauvaux, 1990:46-52). Nenhuma das partes conquistou um lugar concreto nas sociedades civis. É ainda o liberalismo dominante do século XIX que reduz o controle do exercício do poder político a um outro órgão do Estado. Este deve se submeter ao direito que surgiu como por encanto, "autônomo". O mais incrível é que o Estado de direito se parece perigosamente com o direito do Estado, visto que o povo, ao delegar a sua decisão, é afastado deste processo de limitação do poder. Na "democracia representativa liberal", o Estado, sob pretexto de representar a maioria, definiu os direitos, escolheu os indivíduos aos quais este deve ser aplicado, indivíduos que constituem seu objeto concreto, e o quadro no qual isso deve ser feito. A idéia de separação de poderes é reificada a tal ponto que

Estudos Afro-Asiáticos, Ano 23, no 1, 2001, pp. 123-133 
[...] na sua apreciação dos regimes africanos, eles (os juristas e os professores de direito constitucional) sucumbem ao fascínio do princípio da separação de poderes. É assim que, na quase totalidade, os Estados africanos consagram ao menos uma linha de suas constituiçôes a este "princípio imortal" (de Gaudusson e Conac, 1990:6).

O que está em pauta não é a necessidade de limitar o exercício do poder, mas o fato de esvaziá-lo de seu sentido primeiro. Nunca será bastante repetir que, na democracia, a soberania pertence ao povo e não ao Estado e aos partidos políticos. Já não mais se pode confundir as reivindicações destes últimos. Infelizmente, foi o que se passou no já célebre caso de Benguela, no qual um partido político reivindicara, pela força, certas "propriedades", sobrepondo-se ao respeito às regras de direito em vigor e ao próprio povo. A atuação da justiça deve ser considerada além da prática dos tribunais e deve incluir a distribuição das liberdades e das riquezas, dos benefícios e dos encargos econômicos e sociais. Portanto, para garantir sua independência, a justiça deve ser acessível a todos mas, sobretudo, ela deve ser responsável perante o povo. Os juízes, assim como os deputados, devem ser eleitos, existindo também a possibilidade da destituição de ambos. O Estado não deve, em nenhum caso, ser juiz e partido. Sua posição seria, no melhor dos casos, contraditória (instrumento e objeto), e no pior dos casos, a presa daqueles que dominam a economia (instrumento). Estaria, assim, em uma condição de conflito potencial (Fisk, 1989) permanente, entre a busca da justiça e a manutenção de uma ordem social dominada por seu componente econômico: "[...] apesar dos princípios proclamados, a justiça é, na realidade de suas relaçôes com o poder político, um serviço subordinado e estreitamente dependente" (de Gaudusson e Conac, 1990:7).

O papel da justiça é de colocar os limites, mas os limites justos. Além do aspecto formal da justiça como aparelho de Estado, a justiça justa é ainda o refúgio das lutas para pôr um fim à dominação e à opressão (Lyra Filho, 1983:92-127). Não pode, porém, ignorar os interesses e as reivindicaçóes dos dominados. Qualquer regime político não pode pretender uma justiça justa ${ }^{16}$ se não leva em conta os modos de distribuição. À época da reestruturação do sistema mundial, a justiça se situa nas relações que ela tece com outras periferias e os centros do sistema, seja no interior ou mesmo no exterior da sociedade angolana. As implicações destas relações podem ser consideráveis. A política agrícola mundial, por exemplo, pode influenciar a determinação das formas da propriedade fundiária em Angola, a forma de distribuição da riqueza produzida

Estudos Afro-Asiáticos, Ano 23, no 1, 2001, pp. 124-133 
localmente, as reivindicações e os protestos dos produtores angolanos e a ação do aparelho jurídico do Estado.

\section{Um Projeto Nacional e Popular?}

O apoio e as alianças internacionais muito dizem sobre a natureza da partida que se joga em Angola, durante a luta de libertação, depois da independência e até nossos dias (Santos, 1983). Os processos de intermediação da sociedade angolana começam bem antes de 1975. Mas a independência de Angola, apesar do "cabo-de-guerra" entre os movimentos de libertação nacional e seus aliados no nível do sistema mundial, foi um momento propício à operacionalização de um projeto nacional e popular. Esta possibilidade não podia ser admitida pelos países do centro, em particular pelos Estados Unidos e, em nível regional, pela África do Sul. A defesa dos interesses "nacionais" à época coloca como condição mínima uma nova partilha das riquezas no nível da formação social angolana e no nível do sistema mundial. Como condição máxima, esta possibilidade significaria o caminho da ruptura em suas consequiências últimas. É evidente que após 1975, dada a agressão militar da qual foi vítima, Angola não possuía as condições, tanto no nível do desenvolvimento de suas forças produtivas, quanto no que se refere às condições políticas, para realizar tal escolha.

No que concerne à África do Sul, uma Angola independente e capaz de promover tal projeto representaria uma ameaça política para os fundamentos do seu estado racista. Atualmente, apesar dos acontecimentos, a ambição do capitalismo sul-africano permanece intacta: dividir o continente africano em quatro grandes regióes políticas e econômicas controladas por África do Sul, Egito, Nigéria e Quênia, objetivando "garantir" um lugar para o Continente africano no momento da reestruturação do sistema mundial em blocos comuns. O regime sul-africano aspira o reconhecimento de sua força econômica e de sua liderança na integração do Continente ao sistema mundial. É verdade que este é o sonho da burguesia branca sul-africana, e que o regime do ANC tem um outro discurso. Aparentemente, este reconhece, acima de tudo, a necessidade da formação de um bloco econômico regional tendo como base a "reduçãoo" da dominação sul-africana, no qual a base industrial serviria, em primeiro lugar, para encorajar o crescimento das economias da região.

Estudos Afro-Asiáticos, Ano 23, no 1, 2001, pp. 125-133 
Entretanto, os problemas que a África do Sul pós-apartheid tem de enfrentar são de tal ordem que este país será tentado a drenar certas riquezas da região para suprir suas dificuldades. Neste caso, Angola deve se enfraquecer para se tornar um fornecedor de petróleo e de mão-de-obra e um mercado para consumo dos produtos sul-africanos. Os países do centro do sistema mundial não se ocupam da possibilidade de um desenvolvimento capitalista forte em Angola, visto que a África do Sul não necessita de concorrentes que a incomodem e que Angola deve permanecer uma reserva essencial, principalmente de matérias-primas.

A democratização de Angola se apresenta como um fenômeno de "dupla face". Na aparência, é uma imposição dos centros do sistema mundial, em particular dos Estado Unidos, que buscam se apropriar para melhor controlar os contornos e as formas e assegurar as prerrogativas de "ajuste estrutural” em Angola. Não obstante, a periferia angolana deve adotar esta democratização para redefinir suas estratégias nacionais e para reconstruir novas formas de resistência popular. Angola jamais deixou de ser uma periferia africana do sistema mundial. Sua especificidade não resulta do regime político criado após a independência, mas de uma longa luta de libertação nacional. Apesar de suas contradições, esta luta era portadora de uma esperança e de um projeto nacional cuja condição mínima de triunfo repousava na concretização de uma mobilização popular democrática para a construção da nação, nas possibilidades de "ruptura" e na sua condição no interior do sistema mundial.

A democracia é ao mesmo tempo um meio e um fim. Esta condição mínima repousa sobre a existência de forças políticas locais organizadas em torno das aspirações populares e capazes de estabelecer uma relação dinâmica com as sociedades civis. Isto constituiria a base sobre a qual a sociedade angolana poderia criar as condições de realização das legítimas aspirações de seu povo que, assim, poderia criar uma produção local para satisfazer um consumo local, ou seja, um mercado interno, autônomo e endógeno, e os mecanismos nacionais (estatais, privados e coletivos) de distribuição para assegurar a justiça social e econômica.

Este projeto nacional e popular, mesmo antes de qualquer aplicação concreta, causou "arrepios" no centro do sistema mundial. A atitude deste foi de encorajar uma saída cega, acompanhada de um furor destrutivo sem precedente e de uma pilhagem ao estilo medieval dos colonos portugueses primeiro, da burguesia racista sul-africana e dos intermediadores angolanos por último. A história das relações entre Angola e os EUA está ainda para ser escrita,

Estudos Afro-Asiáticos, Ano 23, no 1, 2001, pp. 126-133 
mas parece sempre contrapor o interesse nacional de Angola e a exploração de seus recursos naturais pelas transnacionais americanas à atitude arrogante e imperial dos Estados Unidos. A potência americana, mais que qualquer outra potência central, sempre teve um jogo duplo em um esforço de resguardar os interesses de sua burguesia: apoio ao fascismo colonial português, ao fascismo racista sul-africano e aos interesses do Zaire, ao mesmo tempo em que apoiou os movimentos angolanos em cada época que representavam a maior das possibilidades de intermediação (FNLA, UNITA e, finalmente, MPLA).

Assim, a guerra que explodiu após a independência não pode ser reduzida a uma guerra civil. Ela contrapóe duas facçóes de elites políticas sem a participação verdadeira das sociedades civis, que são as principais vítimas. É, por isso mesmo, uma guerra de agressão: invasões de um exército estrangeiro, financiamento, apoio logístico e material de dois Estados estrangeiros (África do Sul e EUA). A fração dirigente, desta forma, recorreu às forças militares e ao apoio de duas outras potências estrangeiras (Cuba e URSS). Para além dos discursos e da propaganda das elites políticas angolanas e dos Estados do centro, não se trata de uma guerra "étnica", "religiosa" ou de "classes sociais". O conflito entre as duas facções das elites deixa de ter importância, pois o que está em causa é a pretensão, por mínima que seja, de construir um projeto nacional.

Esta guerra que quase aniquila Angola, por não conseguir eliminar a fração dirigente, logrou dividir e tornar intermediária uma boa parte dela. Esta situação representa um risco de suma gravidade para o projeto nacional. Apesar da guerra, o destino do campesinato, todas as etnias confundidas, constitui um exemplo de como as elites fracassaram em seu encontro com a história angolana. Peça-chave na luta pela independência, o campesinato tem sido submetido e maltratado por uns e por outros. Não obstante, existe um outro aspecto capital para este projeto, portador de esperança. A um preço horrivelmente alto, a fração dirigente tem sabido manter intacta a "unidade" do país e preservar a integridade nacional, o que significa que ainda existe um cerne nacionalista capaz de repensar a história do país. Faz-se, porém, urgente pensar a nação e reagrupar todas as forças nacionais e populares, acima dos partidos políticos.

A definição de um projeto nacional e popular "mínimo" deriva diretamente da análise feita da experiência dos anos 1950-1975. A questão crucial que os movimentos de libertação se deveriam colocar às vésperas de 1975 dizia respeito à capacidade

Estudos Afro-Asiáticos, Ano 23, no 1, 2001, pp. 127-133 
de pensar a conquista do poder em termos dos interesses da nação e não da ambição de suas elites dirigentes: como construir um "Estado" que estivesse realmente a serviço da nação e do povo?

Esta questão permanece, ainda hoje, como central na "democratização" angolana. Mas, na ausência de sociedades civis fortes e suficientemente autônomas, capazes de vencer as alianças internas e de definir clara e ativamente o interesse nacional, o "Estado" permanecerá debilitado face à oposição externa (capital mundial) e interna (intermediários). Por isso as eleições eram importantes, se bem que a pressa em realizá-las nessas condições tenha transformado a futura "democracia" em uma noz vazia. A democracia não se constrói em um dia, mas todos os dias. Ela deve abranger todos os campos da sociedade angolana, na qual o ator principal é o povo e o objetivo supremo a construção da nação, isto é, um espaço público (do povo). Estes são permanentes. O demais é efêmero!

\section{Notas}

1. Apesar da guerra, que continuou após a independência, essas conquistas permanecem praticamente intactas. Ver Hodges (1987) e Walker (1990).

2. À medida que o capitalismo colonial português se impunha às sociedades africanas "angolanas", elas eram obrigadas a se submeter, não sem resistências, e passar, sem "aviso prévio”, para uma produção essencialmente agrícola, orientada para o consumo externo (mercado mundial), caracterizada principalmente pela produção de valores de troca (excedentes contínuos e crescentes), em que a propriedade se lhes escapa.

3. Em uma entrevista ao jornal Sunday News (20-8-72), Agostinho Neto, médico, poeta e presidente de um dos movimentos de libertação angolano, já afirmava que lutar pela independência de Angola significa lutar pela construção de uma Angola democrática, próspera e justa, da qual os cidadãos angolanos participariam plenamente, onde poderiam expor suas opiniões, possuiriam as riquezas do país, onde os trabalhadores receberiam um salário justo e onde a justiça seria igual para todos (Bragança e Wallerstein, 1978, v. II: 170).

4. A autonomia da sociedade política se define em relação ao mundo exterior e não em relação às sociedades civis angolanas. Quando nos referimos a elas, estamos nos referindo ao povo, suas açôes (práxis social) e suas instituiçôes, bem como às relações que se criam e se desenvolvem. Estas últimas não se referem apenas às relaçôes de classe. Por outro lado, não se trata aqui do conceito de Estado-nação, identificado com o mundo ocidental, o qual desembocou, na maior parte das vezes, na submissão da nação ao Estado e à supremacia de uma classe social sobre o conjunto da sociedade civil.

5. "Definimos a compradorização como sendo este processo social estrutural de articulação da economia subdesenvolvida à economia desenvolvida. Esta palavra deriva do português "comprador", que significa "intérprete" ou "intermediário". Os compra-

Estudos Afro-Asiáticos, Ano 23, no 1, 2001, pp. 128-133 
dores são indivíduos que atuam como agentes locais dos capitalistas estrangeiros" (Hoogvelt, 1977:100). Optei pelos termos intermediário e intermediação — Nota do tradutor).

6. A título de exemplo, não é raro se prestar contas desta ideologia, apresentada de forma tão sutil na imprensa ocidental. Nos últimos dez anos, a imprensa portuguesa apresentou inúmeras reportagens sobre Angola, nas quais o jornalista disfarça a nostalgia colonial e paternalista sobre o assunto (jamais é ele mesmo quem fala, mas um velho negro angolano que tem "saudades" do colono e dos bons velhos tempos) com imagens do passado.

7. Este ajuste não tem nada a ver com o ajustamento estrutural imposto pelas Instituições Financeiras Internacionais (IFI), dominadas pelos Estados do centro. Aqui, empregamos esta palavra para designar a elaboração e a definição de uma posição e de uma política autônoma, nacional e africana.

8. A propósito das modificações estruturais do sistema mundial e sua influência, devemos nos referir à excelente obra de Immanuel Wallerstein (1991).

9. A reificação é apenas um conceito que nos permite caracterizar o estado de transformação das relações humanas concretas (valor de uso) em relaçōes abstratas entre coisas inertes (valor de troca). Ela é a petrificação das relações humanas, sua coisificação.

10. Isto significa que ela retém o poder de se organizar de maneira independente, fora da esfera política.

11. No sentido empregado por Lyotard e Rogozinski (1985:27-34). Não se trata de negar a importância da universalidade, mas, sobretudo, de recusar particularidades que se impõem à periferia, como os universalismos disfarçados pelos interesses específicos do centro.

12. O desenvolvimento das pesquisas e das lutas das mulheres tem ocasionado um enorme salto qualitativo e quantitativo. O mesmo fenômeno pode ser constatado em relação ao racismo. Como exemplo, citemos: Said (1978); Temu e Swai (1981); Bernal (1987); Thiongo (1987); Amin (1988); Asante (1988); Moghadan (1989); Gheverghese et alii (1990).

13. Ao mesmo tempo em que os centros exigem uma economia cada vez mais aberta em Angola, eles próprios se fecham e multiplicam os controles de seus mercados com uma preocupação excessiva de protecionismo, como demonstram as disputas do GATT -OMC.

14. Isto leva alguns a brincar com fogo, a agir de maneira perigosa, escondendo armas, criando um clima nocivo de instabilidade, de incerteza e de medo.

15. Ver os trabalhos simples e claros de Macpherson $(1965,1977)$.

16. Considera-se uma virtude social no sentido de que caracteriza relaçôes sociais no respeito dos direitos morais, da imparcialidade, da igualdade e do mérito. Ela inclui, logo, a justiça social que se refere à estrutura e às políticas de uma sociedade e à justiça econômica, que diz respeito à distribuição dos benefícios e dos encargos econômicos.

\section{Referências Bibliográficas}

Africa South (1990), "Structural Adjustment Hits Luanda”. Jan./fev., pp. 18-19.

AMIN, Samir (1988), L'Eurocentrisme. Paris, Anthropos/Economica.

Estudos Afro-Asiáticos, Ano 23, no 1, 2001, pp. 129-133 
_ (1989), "La Question Démographique dans le Tiers-Monde Contemporain". Africa Development, v. XIV, no 2, pp. 5-25.

_ (1990a) "A la Périphérie: Fin de la Libération Nationale?". In S. Amin; G. Arrighi; A.G Frank e I. Wallerstein, Le Grand Tumulte?. Paris, La Découverte, pp. 104-52.

_ (1990b), "Le Tiers-Monde et la Révolution". Sociologie et Sociétés, v. XXII, no 1, abril, pp. 93-106.

(1991), L'Empire du Chaos. Paris, L'Harmattan.

ARTHUR, John e SHAW, William H. (eds.) (1991), Justice and Economic Distribution. Englewood Cliffs, NJ, Prentice-Hall.

ASANTE, Molefi Kete (1988), Afrocentricity. Trenton (NJ), Africa World Press.

AUDARD, C.; BOUDON, R. et alii (1988), Individu et Justice Sociale. Paris, Eds. du Seuil.

BERNAL, Martin (1987), Black Athena: The Afroasiatic Roots of Classical Civilization. New Brunswick, Rutgers University Press.

BLOOMFIELD, Richard J. (ed.) (1988), Regional Conflict and U. S. Policy: Angola and Mozambique. Algonac (Mich), World Peace Foundation/Reference Pub.

BOUGUERRA, Mohamed L. (1985), Les Poisons du Tiers-Monde. Paris, La Découverte.

BRAGANÇA, Aquino \& WALLERSTEIN, Immanuel (1978), Quem é o Inimigo? Lisboa, Iniciativas Editorias (3 vols).

BRIEUX (1980), Angola. An III. Paris, Eds. Le Sphinx/ Eds. Rupture.

BRITTAIN, Victoria (1988), Hidden Lives, Hidden Deaths. London, Faber and Faber.

CARNEIRO, Dionisio e ABREU, Marcelo de P. (1989), Angola, Growth \& Adjustment in Scenarios of Peace. Stockholm, Swedish International Development Authority.

CARPENTER, Ted Galen (1991), "The New World Disorder". Foreign Policy, no 84, pp. 24-39.

CHOMSKY, Noam (1989), Necessary Ilusion. Thought Control in Democratic Society. Toronto, CBC Enterprises.

_ (1991), "The Weak Shall Inherit Nothing". The Manchester Guardian Weekly, no 7, abril, p. 8.

COMELIAU, Christian (1991), Les Relations Nord-Sud. Paris, La Découverte.

COQUERY-VIDROVITCH, Catherine \& FOREST, Alain (dir.) (1986), Décolonisations et nouvelles dependences. Lille, Presses Universitaires de Lille.

CORDEN, W. Max (1990), "American Decline and the End of Hegemony". S.A.I.S. Review, vol. $10, \mathrm{n}^{\circ} 2$, pp. 13-26.

CORREIA, Pezarat (1991), Descolonização de Angola. A Jóia da Coroa do Império Português. Lisboa, Editorial Inquérito.

COUVRAT, Jean-François e PLESS, Nicolas (1988), La Face Cachée de l'Économie Mondiale. Paris, Hatier.

CUMINGS, Bruce (1991), "Trilateralism and the New World Order". World Policy Journal, vol. VIII, no 2, pp. 195-222.

DE GAUDUSSON, Jean du Bois e CONAC, Gérard (dir.) (1990), La Justice en Afrique. Paris, Afrique Contemporaine, 156 (Spécial).

DEVOUASSOUX, Christophe e LABÉVIÉRE, Richard (1989), Éloge de Dogmastisme. Lausanne, Eds. De l'Aire.

Estudos Afro-Asiáticos, Ano 23, no 1, 2001, pp. 130-133 
DOWDEN, Richard (1992), "Building Wall Around the First World". The Ottawa Citizen, no 13, March, pp. A1-A2.

ECA-UN (1989), South Africa Destabilization: The Economic Cost of Frontline Resistance to Apartheid. Addis Ababa, Africa Recovery Unit/ U.N. E.C.A, (Oct).

ENNES FERREIRA, Manuel (1990), "A Política de Recuperação Econômica na R. P. de Angola”. Política Internacional, vol. 1, no 1, pp. 107-131.

_ (1991), Angola - Portugal. Do Espaço Econômico Português às Relaçōes Pós-Coloniais. Lisboa, Escher.

EUDES, Yves (1982), La Conquête des Esprits. Paris, Maspero.

FERREIRA, E. de Sousa (1985), "A Lógica da Consolidação da Economia de Mercado em Angola, 1930-1974”. Análise Social, vol. XXI, no 85, pp. 83-110.

FISK, Milton (1989), The State and Justice. Cambridge, UK, Cambridge University Press.

GHEVERGHESE, George et alii (1990), "Eurocentrism in the Social Sciences”. Race \& Class, v. 31, no 4, abril-junho, pp. 1-26.

HARBESON, John W. e ROTHCHILD, Donald (eds.) (s/d), Africa in World Politics. Boulder, CO, Westview Press, pp. 39-68.

HEIMER, Franz-Wilhelm (1980a), "Formation Sociale, Développement Économique et Option Socialiste en Angola”. Genève-Afrique, vol. XVIII, nº 1, pp. 32-43.

_. (1980b), "Sobre a Articulação dos Modos de Produção em Angola. Uma Nota Metodológica”. Análise Social, vol. XIX, nºs 77-78-79, pp. 1091-100.

HERMAN, Edward S. e CHOMSKY, Noam (1988), Manufacturing Consent. New York, Pantheon Books.

HERMELE, Kenneth (1989), "Structure Adjustment \& Political Alliances in Angola, Guinea-Bissau \& Mozambique”. Working Group for Study of Development Strategies, Uppsala University, mimeo.

HODGES, Tony (1987), Angola to the 1990s. The Political for Recovery. London, The Economist Intelligence Unit (EIU), Special Report no 1079.

HOOGVELT, Ankie M. M. (1977), The Sociology of Developing Societies. Atlantic Highlands, NJ, Humanities Press.

HUNT, Michael H. (1990), "American Decline and Great Debate: A Historical Perspective”, S.A.I.S. Review, vol. 10, no 2, pp. 27-40.

HUYGHE, François-Bernard e BARBÉS, Pierre (1987), La Soft Ideologie. Paris, Robert Laffont.

International Commission of Jurist (1981), Development, Human Rights and Rule of Law. Oxford, UK, Pergamon Press.

LATOUCHE, Serge (1989), L'Occidentalisation du Monde. Paris, La Découverte.

(1991), La Planète des Naufragés. Paris, La Découverte.

LAUVAUX, Philippe (1990), Les Grandes Démocraties Contemporaines. Paris, PUF.

LIQUE, René-Jacques (1991), "Cameroun: Le Retour des Blancs". Africa International, $\mathrm{n}^{\circ} 237$, abril, pp. 13-15.

LUBATI, G. (1989), 15 Years of War in Angola: Effects on Children Aged 0-15 Years. W. F. P., Luanda, 31 de julho.

LYOTARD, Jean-François e ROGOZINSKI, Jacob (1985), "La Police de la Pensée". L'Autre Journal, no 10, dezembro, pp. 27-34.

Estudos Afro-Asiáticos, Ano 23, no 1, 2001, pp. 131-133 
LYRA FILHO, Roberto (1983), O Que é o Direito?. São Paulo, Editora Brasiliense.

MACPHERSON, C. B. ([1965] 1990), The Real World of Democracy. Toronto, CBC Enterprises.

_ ([1977] 1984), The Life and Times of Liberal Democracy. Oxford, Oxford University Press.

MARTIN, David e JOHNSON, Phyllis (1989), South Africa and its Neighbours - The Frontline States. Relatório para o Commonwealth Committee of Foreign Ministers on Southern Africa, Harare, 6-8 de fevereiro.

MBEMBA, Jean-Martin (1990), L'Autre Mémoire du Crime Contre l'Humanité. Paris, Présence Africaine.

MEYNS, Peter (1984), "O Desenvolvimento da Economia Angolana a partir da Independência: Problemas da Reconstrução Nacional”. Revista Internacional de Estudos Africanos, no 2, dezembro, pp. 121-61.

MILLER, David (1989), Social Justice. New York, Oxford University Press.

MOGHADAN, Val (1989), "Against Eurocentrism and Nativism: A Review Essay on Samir Amin's Eurocentrism and Other Texts”. Socialism and Democracy, no 9, pp. 81-104.

MORAIS, Eduardo S. de (1990), “As Mudanças Econômicas e o seu Impacto sobre a Família”. Seminário Internacional sobre a Família Africana, Luanda, Sec. de Estado dos Assuntos Sociais/União Internacional dos Organismos Familiares, pp. 61-65.

PEAN, Pierre (1984), L'Argent Noir. Paris, Fayard.

PEARCE, Richard (1989), The Social Dimensions of Adjustment in Angola. Relatório do Food Studies Group, University of Oxford-Unicef.

RUFIN, Jean-Christophe (1991), L'Empire et les Nouveaux Barbares. Paris, J. C. Lattès.

SAID, Edward (1978), Orientalism. New York, Vintage Books.

SANDERS, Jerry W. (1991), "Retreat from World Order: The Perils of Triumphalism". World Policy Journal, vol. VIII, no 2, pp. 227-50.

SANTOS, Daniel dos (1983), "Cabinda: The Politics of Oil in Angola's Enclave". In R. Cohen, (ed.), African Islands and Enclaves. Beverly Hills, CA, Sage Publications, pp. 101-117.

. (1987), "L'État Périphérique et les Classes Sociales. Référence Particulière à l'Afrique”, Critiques Socialistes, no 3, pp. 141-159.

SFIA, Mohamed S. (1979), "Système Capitaliste Mondial et Transition au Socialisme". Sociologie et Sociétés, v. XI, no 2, outubro, pp. 59-67.

TEMU, A. e SWAI, B. (1981), Historians and Africanist History. London, Zed Press.

TERRAY, Emmamuel; MOSCOVICI, Serge; DOISE, Willem et alii (1990), Le Consensus, Nouvel Opium? Paris, Editions du Seuil (Le Genre Humain).

THIONGO, Ngügí Wa (1987), Decolonizing the Mind. London, James Currey.

TORRES, Adelino (1983), "Pacto Colonial e Industrialização de Angola (Anos 60-70)", Análise Social, vol. XIX, nos 77-78-79, pp. 1101-1119.

_ (1990), “Angola e Mozambique: Estratégias de Desenvolvimento". Estratégia, no 7 , pp. $105-128$.

UNICEF (1989), Annual Report on Angola \& São Tomé and Príncipe. Luanda, Unicef.

VIDAL, John (1992), "Banco Mundial Defende que os Ricos Poluam os Pobres”. O Jornall ECONOMIA, no 21, fevereiro, p. 19.

Estudos Afro-Asiáticos, Ano 23, no 1, 2001, pp. 132-133 
WALKER, Graham (1990), Angola: The Promise of Riches. London, Africa File Ltd, Special Report.

WALLERSTEIN, Immanuel (1983), Historical Capitalism. London, Verso Editions.

_ (1991), Geopolitics and Geoculture. Cambridge, UK, Cambridge University Press/Eds. de la Maison des Sciences de I'Homme.

WORLD BANK (1991), Angola. An Introduction Economic Review. Washington (D.C.), The World Bank (Country Study).

ZIEGLER, Jean (1989), "Critique de la Société de Communication". Le Nouvel Afrique-Asie, no 3, dezembro.

Estudos Afro-Asiáticos, Ano 23, no 1, 2001, pp. 133-133 